\title{
Pengaruh Model Pembelajaran (SAVI) Berbasis (TIK) Terhadap Kompetensi Pengetahuan Matematika
}

\author{
I Gst. Ayu Sri Anggreni ${ }^{1}$, I Wayan Wiarta ${ }^{2}$, DB.Kt. Ngr. Semara Putra ${ }^{3}$ \\ ${ }^{123}$ Prodi Pendidikan Guru Sekolah Dasar, FIP \\ Universitas Pendidikan Ganesha, \\ Singaraja, Indonesia \\ e-mail : ayusrianggreni22@gmail.com ${ }^{1}$, iwayan.wiarta@undiksha.ac.id ${ }^{2}$, \\ ngurahsemara@yahoo.com ${ }^{3}$
}

\begin{abstract}
Abstrak
Penelitian ini bertujuan untuk mengetahui pengaruh model pembelajaran Somatic, Auditory, Visual, Intelectual berbasis TIK terhadap kompetensi pengetahuan matematika siswa kelas V SD Gugus Letkol Wisnu. Jenis penelitian ini adalah eksperimen semu, dengan rancangan nonequivalent control group design. Populasi dari penelitian ini adalah seluruh kelas V di SD Gugus Letkol Wisnu. Sampel diambil dengan teknik acak kelompok. Sampel dalam penelitian ini adalah kelas V SD Negeri 12 Peguyangan yang berjumlah 43 siswa dan kelas V SD Negeri 5 Peguyangan yang berjumlah 35 siswa. Data kompetensi pengetahuan matematika dikumpulkan dengan instrument tes pilihan ganda. Selanjutnya data dianalisis dengan menggunakan uji-t. Hasil dari uji hipotesis diperoleh $t_{\text {hitung }}=4,05>t_{\text {tabel }}=2,000$ dengan tarafsignfikansi $5 \%$ dan $\mathrm{dk}=76$. Hal ini berarti terdapat perbedaan yang signifikan kompetensi pengetahuan matematika antara kelompok siswa yang dibelajarkan melalui model pembelajaran Somatic, Auditory, Visual, Intelectual berbasis TIK kelompok siswa yang dibelajarkan melalui pembelajaran konvensional pada siswa kelas V SD Gugus Letkol Wisnu Tahun Ajaran 2018/2019. Rata-rata GSn kelompok eksperimen $X_{1}=0,542>X_{2}=0,392$ ratarata GSn kompetensi pengetahuan matematika kelompok control. Jadi, model pembelajaran Somatic, Auditory, Visual, Intelectual berbasis TIK berpengaruh terhadap kompetensi pengetahuan matematika siswa kelas V SD Gugus Letkol Wisnu.
\end{abstract}

Kata-kata kunci: (TIK), kompetensi, pengetahuan, matematika, (SAVI)

\begin{abstract}
This research aimed to determine the influence of Somatic learning model, Auditory, Visual, ICT-based Intelectual to mathematic competency of the fifth-grade student at SD Gugus Letkol Wisnu in 2018/2019 academic year. This type of research is a pseudo experiment, with Nonequivalent control group design. The population of this study was all fifth gradestudents at SD Gugus Letkol Wisnu which amounted to 335 students. Samples were taken with a random group technique. The sample in this study was fifth grade students at SD Negeri 12 Peguyangan, amount to 43 students and fifth grade students at SD Negeri 5 Peguyangan, amount to 35 students. The Mathematical Knowledge Competency Data was collected with multiple choice test instruments. The Mathematical Knowledge Competency test was given at post-test in writing. Further data was analyzed with Test-T. The result of the hypothesis test was Thitung $=4.05>$ this $=2.000$ with a Tarafsignfikansi $5 \%$ and $D K=76$. It means that there is a significant difference in the competence of mathematical knowledge between groups of students who taught through Somatic's learning model, Auditory, Visual, ICT-based Intelectual groups of students that are taught through Conventional learning in fifth grade students at $S D$ Gugus Letkol Wisnu in 2018/2019 academic year. Average GSn Group Experiments X1 $=0.542$ $>$ X2 $=0.392$ average GSn competency Knowledge Math Group control, so it can be concluded that the learning model Somatic, Auditory, Visual, ICT-based Intelectual influence on Competency Knowledge mathematics of fifth grade students at SD Gugus Letkol Wisnu in 2018/2019 academic year.
\end{abstract}

Keywords: (ICT), mathematical knowledge competencies, (SAVI) 


\section{Pendahuluan}

Pendidikan merupakan sasaran penting untuk memajukan suatu bangsa yang ditentukan oleh kualitas sumber daya manusia dalam menjamin keberlangsungan pembangunan suatu bangsa. Pendidikan berlangsung dalam segala lingkungan baik yang khusus diciptakan untuk kepentingan pendidikan maupun ada yang sendirinya. Pendidikan berlangsung seumur hidup di setiap saat selama ada pengaruh lingkungan. Kegiatan pendidikan terentang dari bentuk bentuk yang misterius atau tak disengaja sampai yang terprogram. Pendidikan berbentuk segala macam pengalaman belajar dalam hidup. Pendidikan berlangsung dalam berbagai bentuk, pola dan lembaga. Pendidikan dapat terjadi sembarang, kapan dan dimana pun dalam hidup. Pendidikan lebih berorientasi pada peserta didik.

Dalam pembelajaran matematika diharapkan kompetensi pengetahuan matematika siswa mencapai KKM, pembelajaran yang menyenangkan, pembelajaran yang bervariasi sehingga kompetensi pengetahuan matematika siswa tercapai secara optimal. Berdasarkan observasi yang telah dilakukan pada hari Kamis, 10 Januari 2019 dengan wali kelas V di SD Gugus Letkol Wisnu Denpasar Utara dalam proses pembelajaran terutama pada mata pelajaran Matematika masih banyak kelemahan dilihat dari kompetensi pengetahuan Matematika siswa yang sebagian besar belum mancapai nilai Kriteria Ketuntasan Minimal (KKM). Dimana KKM untuk kompetensi pengetahuan Matematika yang diharapkan dalam Kurikulum 2013 adalah 71,00 . Hal tersebut dapat dilihat dari nilai raport semester ganjil dari 335 siswa yang ada di SD Gugus Letkol Wisnu 79 siswa mendapatkan predikat (A), 81 siswa mendapatkan predikat (B), 112 orang siswa mendapatkan predikat (C). dan 63 siswa mendapatkan predikat (D). Dari 335 siswa kelas $V$ sebanyak 160 siswa yang sudah mencapai KKM, sedangkan 175 siswa yang belum mencapai KKM. Faktor tersebut disebabkan karena pembelajaran Matematika dianggap sebagai pelajaran yang membosankan dan sulit dipahami, model pembelajaran yang diterapkan di sekolah masih kurang bervariasi, proses pembelajaran masih bersifat monoton dan kurang menarik mengakibatkan kejenuhan dalam diri siswa, sehingga keterlibatan siswa dalam proses pembelajaran cenderung pasif. Selain itu kurangnya pemahaman siswa Kelas V SD Gugus Letkol Wisnu terhadap mata pelajaran matematika. Sehingga berdampak pada kompetensi pengetahuan matematika yang dimiliki siswa kurang optimal.

Oleh karena itu, berbagai upaya untuk meningkatkan mutu pendidikan harus selalu dilakukan baik dari model pembelajaran yang digunakan harus inovatif dan dari segi sarana dan prasarana. Model pembelajaran yang digunakan dalam proses pembelajaran dapat dianggap sebagai suatu prosedur atau proses yang teratur, suatu jalan atau cara yang teratur untuk melakukan sesuatu. Model pembelajaran yang dapat memberikan kesempatan bagi siswa untuk membangun pengetahuannnya sendiri dan menyediakan kesempatan yang banyak untuk berinteraksi sosial dengan temannya adalah model pembelajaran Somatic, Auditory, Visual, Intelectual.

Menurut Nurokhmatillah (dalam atun,2018:92), model pembelajaran Somatic, Auditory, Visual, Intelectual adalah model pembelajaran yang melibatkan gerakan fisik dengan aktivitas intelektual dan penggunaan indra secara simultan. Penggunaan indra secara simultan dapat memfasilitasi atau memberikan kesempatan kepada seluruh siswa, untuk dapat belajar sesuai dengan gaya belajar mereka yang beragam.

Hal tersebut sejalan dengan pendapat Julianikah (dalam atun,2018) yang menyatakan bahwa model pembelajaran Somatic, Auditory, Visual, Intelectual merupakan suatu model pembelajaran yang menekankan bahwa belajar harus melibatkan semua panca indra yang dimiliki oleh siswa. Panca indra siswa harus dapat dimanfaatkan seoptimal mungkin agar dapat memahami tentang konsep maupun permasalahan.

Berdasarkan pendapat tersebut dapat dirangkum bahwa model pembelajaran Somatic, Auditory, Visual, Intelectual adalah suatu model pembelajaran dengan memanfaatkan seoptimal mungkin seluruh panca indra yang dimiliki oleh siswa dan kemampuan intelektual siswa dalam menangkap suatu informasi. Pembelajaran Somatic, Auditory, Visual, Intelectual tidak hanya mengaktifkan pikiran atau intelektual siswa saja, tetapi juga terdapat aktivitas tubuh secara keseluruhan. Pembelajaran Somatic, Auditory, Visual, Intelectual ini dapat memberikan kesempatan belajar siswa dalam memperoleh informasi sesuai dengan gaya belajar masing masing siswa. Untuk menunjang pelaksanaan model pembelajaran Somatic, Auditory, Visual, Intelectual diperlukan bukti yang dapat menunjukan peningkatan kompetensi pengetahuan matematika siswa. Teknologi Informasi dan Komunikasi (TIK) merupakan satu ketentuan yang 
digunakan oleh guru untuk alat atau media pembelajaran yang digunakan agar siswa lebih tertarik dalam pembelajaran dan diharapkan lebih aktif pada saat jam pembelajaran.

Dalam pembelajaran berbasis TIK, TIK berperan sebagai media penghubung untuk menyampaikan transfer ilmu pengetahuan dari pendidik kepada peserta didik. Dua unsur penting dalam proses transfer ilmu pengetahuan yaitu unsur media dan pesan yang disampaikan melalui media tersebut. Unsur media menggambarkan TIK sebagai jaringan infrastruktur yang menghubungkan pendidik dengan peserta didik, sedangkan unsur pesan menggambarkan konten pembelajaran digital. Model pembelajaran Somatic, Auditory, Visual, Intelectual berbasis TIK diduga dapat berpengaruh terhadap kompetensi pengetahuan matematika.

Berdasarkan paparan latar belakang tersebut, untuk mengoptimalkan proses pembelajaran matematika di SD maka dilakukan penelitian tentang Pengaruh Model Pembelajaran Somatic, Auditory, Visual, Intelectual berbasis TIK Terhadap Kompetensi Pengetahuan Matematika Kelas V SD Gugus Letkol Wisnu Tahun Ajaran 2018/2019.

\section{Metode}

Penelitian ini dilaksanakan pada semester 2 tahun ajaran 2018/2019 di kelas V SD Gugus Letkol Wisnu Denpasar Utara. Jenis penelitian yang digunakan adalah penelitian eksperimen yaitu quasi experiment design (eksperimen semu). Sugiyono (2014:114) memaparkan bahwa desain eksperimen semu (quasi experiment design) mempunyai kelompok control tetapi tidak dapat befungsi sepenuhnya untuk mengontrol variabel-variabel luar yang memengaruhi pelaksanaan eksperimen. Subjek penelitian atau partisipan penelitian tidak dipilih secara acak untuk dilibatkan dalam kelompok eksperimen dan kelompok kontrol. Tujuan dari penelitian ini adalah untuk mengetahui pengaruh model pembelajaran Somatic, Auditory, Visual, Intelectual berbasis TIK terhadap kompetensi pengetahuan matematika kelas V SD Gugus Letkol Wisnu Denpasar Utara.

Desain eksperimen semu yang digunakan dalam penelitian ini adalah Nonequivalent Control Group Design.Rancangan penelitian ini secara skematis dapat di gambarkan sebagai berikut.

\begin{tabular}{|cccl|}
\hline $\mathrm{O}_{1}$ & $\mathrm{X}$ & $\mathrm{O}_{2}$ & (eksperimen) \\
\hline $\mathrm{O}_{3}$ & & $\mathrm{O}_{4}$ & (kontrol) \\
\hline
\end{tabular}

Gambar 01 Rancangan penelitian non-equivalent control group design

(Sumber: Setyosari, 2015:211)

$\begin{array}{lll}\text { Keterangan : } & \\ \mathrm{O}_{1} & = & \text { pretest pada kelompok eksperimen } \\ \mathrm{O}_{2} & = & \text { posttest pada kelompok eksperimen } \\ \mathrm{O}_{3} & = & \text { pretest pada kelompok kontrol } \\ \mathrm{O}_{4} & = & \text { posttest padakelompok kontrol } \\ \mathrm{X} & = & \text { Perlakuan yang diberikan pada kelompok eksperimen }\end{array}$

Dalam rancangan penilitian non-equivalent control group design, ada dua kelompok subjek, satu kelompok mendapat perlakuan dan satu kelompok lagi sebagai kelompok kontrol. Sebelum pemberian perlakuan, dilakukan pengukuran awal atau pretest terhadap kedua kelompok tersebut. Selanjutnya, pada kelompok eksperimen diberikan perlakuan $(X)$ yaitu, model pmbelajaran Somatic, Auditory, Visual, Intelectual berbasis TIK, sedangkan untuk kelas kontrol dibelajarkan menggunakan pembelajaran konvensional. Setelah itu, kedua kelompok dilakukan pengukuran pasca pemberian perlakuan atau postest. Prosedur penelitian ini terdiri dari tiga tahap yaitu tahap persiapan eksperimen, tahap pelaksanaan esperimen, dan tahap akhir eksperimen. Adapun uraian dari setiap tahapan tersebut adalah sebagai berikut.

Pada tahap persiapan ini kegiaan yang dilakukan adalah : (1). melakukan wawancara dengan kepala gugus Letkol Wisnu dan wali kelas V di masing - masing sekolah di Gugus Letkol Wisnu untuk mengetahui masalah yang terdapat di Gugus Letkol Wisnu; (2). menyusun RPP (Rencana Pelaksanaan Pembelajaran) dan LKS; (3). mempersiapkan model pembelajaran Somatic, Auditory, Visual, Intelectual berbasis TIK. (4). menyusun instrumen penelitian pre-test dan post-test; (5). mengkonsultasikan instrumen penelitian bersama dosen pembimbing; (6). mengkonsultasikan RPP bersama dosen pembimbing; (7). menentukan 
sampel berupa kelas dari populasi dengan teknik random sampling; (8). memberikan pre-test kepada kelompok eksperimen dan kelompok kontrol; (9).Menyetarakan kelompok dengan menganalisis data pre-test kelompok eksperimen dan kontrol dengan teknik uji-t.

Pada tahap pelaksanaan kegiatan yang dilakukan antara lain : (1). melaksanakan penelitian yaitu memberikan perlakuan kepada kelompok eksperimen berupa model pembelajaran Somatic, Auditory, Visual, Intelectual berbasis TIK; (2). perlakuan diberikan sebanyak 6 kali di kelas eksperimen; (3). memberikan post-test pada akhir eksperimen, baik untuk kelompok eksperimen maupun kontrol. Saat tahap akhir, kegiatan yang dilakukan adalah : (1). menganalisis data hasil penelitian; (2). melakukan uji hipotesis.

Dalam melaksanakan penelitian, peneliti terlebih dahulu harus mencari objek yang akan diteliti. Objek tersebut disebut dengan populasi dan sampel.."Populasi merupakan keseluruhan dari objek, orang, peristiwa, atau sejenisnya yang menjadi perhatian dan kajian dalam penelitian" (Setyosari,2015:221). Populasi diartikan wilayah generalisasi yang terdiri atas obyek/subyek yang mempunyai kualitas dan karakteristik tertentu yang ditetapkan oleh peneliti untuk dipelajari dan kemudian ditarik kesimpulannya (Sugiyono, 2017:215). Jadi dapat disimpulkan pengertian populasi adalah kumpalan obyek/subyek, orang, peristiwa atau sejenisnya yang memiliki karakteristik tertentu yang ingin diteliti oleh peneliti lalu dipelajari dan ditarik kesimpulannya.

Sebagaimana telah dijelaskan sebelumnya bahwa penelitian ini dilaksanakan di SD Gugus Letkol Wisnu Denpasar Utara.Sehingga populasi dari penelitian ini adalah seluruh kelas V SD Gugus Letkol Wisnu Denpasar Utara Tahun Pelajaran 2018/2019. Terdapat 7 (tujuh) SD Negeri di Gugus Letkol Wisnu Denpasar Utara, yaitu: SD N 1 Peguyangan, SD N 3 Peguyangan, SD N 5 Peguyangan, SD N 6 Peguyangan, SD N 10 Peguyangan, SD N 11 Peguyangan, dan SD N 12 Peguyangan. Jumlah populasi dari penelitian ini adalah 335 orang.

Dari populasi yang telah ditentukan maka selanjutnya diambil perwakilan dari populasi tersebut yang dianggap mewakili seluruh populasi. Perwakilan dari populasi yang mewakili populasi disebut dengan sampel. "Sampel adalah suatu kelompok yang lebih kecil atau bagian dari populasi secara keseluruhan" (setyosari,2015:221).

Dari populasi kelas V SD Gugus Letkol Wisnu yang terdiri dari 9 kelas dipilih 2 kelas sebagai sampel penelitian, yaitu kelas eksperimen dan kelas kontrol. Untuk menentukan kelas eksperimen dan kelas kontrol teknik yang digunakan untuk pengambilan sampel pada penelitian ini adalah Random Sampling, yang di random kelasnya. Cara yang digunakan adalah dengan cara pengundian. Pengambilan sampel dengan teknik random sampling dapat dilakukan dengan cara undian (Agung, 2014:71). Langkah-langkah penentuan sampel adalah sebagai berikut.

Pada tahap pertama dilakukan teknik pengambilan sampel dengan cara undian, sehingga semua anggota populasi memiliki kesempatan yang sama untuk menjadi sampel penelitian. Cara undian dilakukan dengan menulis semua nama kelas V di seluruh SD Gugus Letkol Wisnu populasi pada masing-masing kertas yang jumlahnya 9 , kemudian kertas digulung dan dimasukan ke dalam kotak dan dikocok untuk memilih dua kelas yang dijadikan sampel penelitian. Dari kedua kelas yang keluar diundi kembali untuk menentukan kelompok eksperimen dan kelompok kontrol. Berdasarkan undian yang dilakukan, kelas V SD Negeri 12 Peguyangan muncul pertama yang dijadikan sebagai kelas eksperimen sedangkan kelas V SD Negeri 5 Peguyangan muncul pada undian kedua yang dijadikan sebagai kelompok kontrol.

Pada tahap kedua, dua kelas terpilih melalui pengundian dilakukan uji kesetaraan sampel dengan diberikan prates, nilai atau skor dari hasil prates yang dilakukan tersebut untuk mengetahui tingkat kesetaraan sampel. Nilai atau skor dari hasil prates tersebut diuji kesetaraanya menggunakan uji t bentuk polled varians.

$$
t=\frac{\bar{X}_{1}-\bar{X}_{2}}{\sqrt{\frac{\left(n_{1}-1\right) S_{1}^{2}+\left(n_{2}-1\right) S_{2}^{2}}{n_{1}+n_{2}-2}\left(\frac{1}{n_{1}}+\frac{1}{n_{2}}\right)}}
$$

Keterangan :

$\mathrm{X}_{1} \quad=$ rata-rata skor prates sampel 1

$\mathrm{X}_{2_{2}} \quad=$ rata-rata prates sampel

$\mathrm{S}_{1}{ }^{2} \quad=$ varian sampel 1

$\mathrm{S}_{2}{ }^{2}=$ varian sampel 2

$\mathrm{n}_{1} \quad=$ jumlah sampel 1

$\mathrm{n}_{2} \quad=$ jumlah sampel 2 
Kriteria pengujian, jika $t_{\text {hitung }}>t_{\text {tabel }}$, maka $\mathrm{H}_{\mathrm{O}}$ ditolak dan $\mathrm{H}_{\mathrm{a}}$ diterima, sehingga kelompok tidak setara. Sebaliknya $t_{\text {hitung }} \leq t_{\text {tabel }}$ maka $H_{\circ}$ diterima dan $H_{a}$ ditolak, sehingga kelompok setara. Pada taraf signifikansi $5 \%$ dengan derajat kebebasan $(\mathrm{dk}=\mathrm{n} 1+\mathrm{n} 2-2)$.

Sebelum uji kesetaraan menggunakan uji-t, maka data hasil pre-test diuji prasyarat yaitu uji normalitas sebaran data dan uji homogenitas varians. Uji normalitas kedua sampel dilakukan menggunakan analisis Kolmogorov-Smirnov .

Setelah dilakukan analisis terhadap pre-test kompetensi pengetahuan matematika, maka diperoleh hasil bahwa pre-test kompetensi pengetahuan matematika kelas V SD Gugus Letkol Wisnu Tahun Ajaran 2018/2019 berdistribusi normal dan homogen. Berdasarkan hasil uji-t yang dilakukan diperoleh bahwa kedua kelas tersebut setara dengan hasil analisis menunjukkan $t_{\text {hitung }}$ $\leq \mathrm{t}_{\text {tabel }}$ maka $\mathrm{H}_{\mathrm{O}}$ diterima yang artinya kedua kelas setara.

Dalam penelitian ini data yang akan dianalisis adalah data kompetensi pengetahuan matematika pada siswa kelas V SD Gugus Letkol Wisnu tahun Pelajaran 2018/2019 sebagai sampel. Untuk mendapatkan data tersebut digunakan metode tes. Tes merupakan alat atau prosedur yang digunakan untuk mengetahui atau mengukur sesuatu dalam suasana, dengan cara dan aturan-aturan yang sudah ditentukan" (Arikunto, 2015:67). Tes kompetensi pengetahuan matematika yang digunakan dalam penelitian ini adalah tes objektif.

Instrumen pengumpulan data yang digunakan dalam penelitian ini adalah tes kompetensi pengetahuan matematika. Sebelum memberikan tes tersebut kepada siswa dilakukan pengujian untuk menguji kelayakan instrumen. Tes yang baik harus mampu mengukur apa yang akan diukur (aspek validitas) dan konsisten atau stabil dalam mengukur apa yang akan diukur (aspek reliabilitas). Tes yang akan digunakan untuk mengukur kompetensi pengetahuan berupa tes objektif dalam bentuk pilihan ganda biasa dilakukan pengujian instrumen yaitu uji validitas, uji daya beda, uji indeks kesukaran, dan uji reliabilitas. Jumlah butir soal disusun berdasarkan kisi-kisi tes kompetensi pengetahuan matematika sebanyak 40 butir soal yang kemudian di uji cobakan pada kelas yang jenjangnya lebih tinggi.

Menurut Sugiyono (2017:102) "instrumen penelitian adalah suatu alat ukur yang digunakan dalam penelitian". Instrumen yang digunakan untuk mengumpulkan data kompetensi pengetahuan matematika adalah tes. "Tes merupakan alat atau prosedur yang digunakan untuk mengetahui atau mengukur sesuatu dalam suasana, dengan cara dan aturan-aturan yang sudah ditentukan" (Arikunto, 2015:67). Tes kompetensi pengetahuan matematika yang digunakan dalam penelitian ini adalah tes objektif. Tes objektif adalah tes yang dalam pemeriksaanya dapat dilakukan secara objektif. "Tes objektif adalah tes yang disusun sedemikian rupa dan telah disediakan alternatif jawabannya" (Yusuf,2015:96). Tes objektif terdiri dari beberapa bentuk yaitu: (1) tes objektif bentuk benar-salah, (2) tes objektif bentuk menjodohkan, (3) tes objektif bentuk jawaban singkat, (4) tes objektif bentuk pilihan ganda. Dalam instrumen penelitian ini menggunakan bentuk pilihan ganda biasa dengan empat pilihan jawaban.

Sebelum memberikan tes kepada siswa, terlebih dahulu menguji kelayakan instrumen tes yang akan digunakan untuk mengukur pemahaman konsep matematika. Pengujian instrumen yang dilakukan yaitu:

Uji Validitas, Uji Validitas instrument adalah derajat yang menunjukkan di mana suatu tes mengukur apa yang hendak diukur. Menurut Agung (2013:77) Sebuah tes dikatakan valid apabila tes tersebut mengukur apa yang hendak diukur (ketetapan alat ukur dengan hal yang diukur). Jadi sangat perlu dilakukan uji validitas pada suatu instrumen sebelum diuji cobakan. Uji validitas yang digunakan dalam penelitian ini yaitu validitas isi dan validitas butir.

"Validitas isi adalah validitas dari segi isinya atau apabila mengukur tujuan khusus tertentu yang sejajar dengan isi atau materi pelajaran yang diberikan" (Agung, 2013:78). Uji validitas isi dalam penelitian ini adalah menguji kisi-kisi. Pengujian validitas isi dilakukan untuk menguji valid atau tidaknya suatu tes dari segi isinya. Validitas isi dapat dilakukan dengan cara menyesuaikan item tes dengan materi kurikulum atau materi buku pelajaran. Untuk mendapatkan validitas isi dari tes perolehan kompetensi pengetahuan matematika maka ditempuh cara dengan menyusun soal berdasarkan kisi - kisi. Tes kompetensi pengetahuan matematika dikatakan valid apabila materi tes tersebut betul-betul representatif terhadap bahan pembelajaran yang akan dibelajarkan terhadap siswa. Sedangkan Untuk mengukur validitas butir tes penguasaan kompetensi pengetahuan matematika dalam bentuk pilihan ganda (objektif) digunakan rumus koefisien korelasi point biserial $\left(r_{\mathrm{pbi}}\right)$ karena bersifat dikotomi. 
Kemudian bandingkan nilai yang diperoleh yakni membandingkan nilai $r_{\text {hitung }}$, dengan $r_{\text {tabel, }}$ jika $r_{\text {hitung }} \geq r_{\text {tabel }}$ maka dalam katagori valid dan jika $r_{\text {hitung }}<r_{\text {tabel }}$ berarti tidak valid dengan taraf signifikan sebesar $5 \%$.

Uji Daya Beda, daya pembeda (DP) atau uji daya tes adalah "kemampuan suatu soal untuk membedakan antara siswa yang pandai dengan siswa yang kurang pandai" (Arikunto, 2015:226). Dengan kata lain daya pembeda butir soal adalah menyatakan seberapa jauh kemampuan butir soal tersebut mampu membedakan antara siswa yang mengetahui jawaban benar dengan siswa yang tidak dapat menjawab soal tersebut.

Derajat daya pembeda (DP) suatu butir soal dinyatakan dengan indeks diskriminasi yang bernilai $-1,00$ sampai dengan 1,00. Apabila indeks diskriminasi makin mendekati nilai 1,00 ini berarti daya pembeda soal akan semakin baik, begitu juga sebaliknya, jika indeks diskriminasi suatu soal mendekati nilai 0,00 maka daya pembeda soal tersebut sangat rendah. Jika suatu butir soal memiliki indeks diskriminasi 0,00 berarti soal tersebut tidak memiliki daya pembeda, artinya siswa yang berkemampuan tinggi dan kemampuannya rendah mampu menjawab benar soal tersebut. Namun jika indeks diskriminasi butir soal bernilai negatif $(0,00$ sampai $-1,00$ ) berarti butir soal tersebut dinyatakan mempunyai daya pembeda yang tidak baik dan soal tersebut sebaiknya tidak digunakan.

Sebelum melakukan uji daya beda, seluruh testi dikelompokkan menjadi dua kelompok, yaitu kelompok berkemampuan tinggi (kelompok atas) dan kelompok berkemampuan rendah (kelompok bawah). Proses penentuan kelompok atas dan kelompok bawah dilakukan dengan cara mengurutkan skor yang diperoleh siswa, dari skor tertinggi hingga skor terendah. Penentuan kelompok atas dan kelompok bawah ditentukan dengan mengambil $50 \%$ skor teratas sebagai kelompok atas $\left(\mathrm{J}_{\mathrm{A}}\right)$ dan $50 \%$ skor terbawah sebagai kelompok bawah $\left(\mathrm{J}_{\mathrm{B}}\right)$ dari jumlah sampel. Indeks daya beda yang digunakan untuk tes dalam penelitian ini adalah dari 0,21 sampai 1,00 dalam kategori cukup, jelek, baik dan baik sekali.

Indeks Kesukaran atau Tingkat kesukaran adalah proporsi kesanggupan siswa untuk menjawab tes yang diberikan dengan benar. Tingkat kesukaran bertujuan untuk menentukan apakah suatu instrumen terlalu sukar atau terlalu mudah bagi siswa yang hendak diukur. Angka yang dapat memberikan petunjuk mengenai tingkat kesulitan item butir tes difficulty index (angka indeks kesukaran item) yang pada umumnya dilambangkan dengan huruf $P$ yaitu singkatan dari proporsi indeks kesukaran item besarannya berkisaran antara 0,00 sampai dengan 1,00. Angka indeks 0,00 dapat dikatakan indeks kesukaran paling rendah dan 1,00 dapat dikatakan indeks kesukaran paling tinggi. Angka indeks kesukaran sebesar 0,00 merupakan petunjuk bahwa butir item tersebut terlalu sukar, sebaliknya apabila indeks kesukaran soal sebesar 1,00 menyatakan bahwa butir item yang bersangkutan adalah termasuk dalam kategori item yang terlalu mudah.

Uji Reliabilitas suatu penelitian berhubungan dengan masalah kepercayaan. Arikunto (2015:100) berpendapat bahwa "suatu tes dapat dikatakan mempunyai taraf kepercayaan yang tinggi jika tes tersebut dapat memberikan hasil yang tetap". Reliabilitas atau tingkat keajegan butir tes, yakni sejauh mana suatu tes dapat dipercaya untuk menghasilkan skor yang ajeg atau konsisten (tidak berubah-ubah). Uji reliabilitas tes yang bersifat dikotomi kemudian dianalisis dengan menggunakan rumus Kuder Richardson 20 (KR-20).

Dalam pemberian interpretasi terhadap koefesien reliabilitas tes nilai $r_{11}$ pada umumnya digunakan kriteria apabila nilai $r_{11} \geq 0,70$ berarti tes kompetensi yang sedang diuji reliabilitasnya dinyatakan telah reliable, namun apabila $r_{11}<0,70$ berarti tes hasil belajar yang sedang diuji reliabilitasnya dinyatakan unreliable.

Setelah data dikumpulkan, data tersebut perlu dianalisis. Teknik analisis data yang digunakan untuk menganalisis data dalam penelitian ini adalah teknik analisis statistik inferensial. Pada penelitian ini sebelum analisis data melalui statistik inferensial dilakukan, terlebih dahulu hasil pre-test dan pos-test pada kedua kelompok sampel dalam penelitian ini dinormalisasi dengan menggunakan gain skor ternormalisasi. Setelah itu dianalisis menggunakan analisis statistik inferensial. Analisis statistisk inferensial adalah suatu cara pengolahan data yang dilakukan dengan cara menerapkan rumus-rumus statistik inferensial untuk menguji suatu hipotesis penelitian yang diajukan peneliti, dan kesimpulan berdasarkan hasil pengujian terhadap hipotesis (Agung, 2014:110). Dalam penelitian ini teknik analisis yang digunakan untuk menguji hipotesis menggunakan uji-t. Sebelum dilakukan uji-t, terlebih dahulu harus memenuhi uji prasyarat analisis, yaitu dengan uji normalitas sebaran data dan uji homogenitas varians. 


\section{Hasil dan Pembahasan}

Dekripsi data hasil penelitian ini memaparkan mengenai perolehan hasil post-test pada kelompok eksperimen dan kelompok kontrol di SD Gugus Letkol Wisnu Tahun Ajaran 2018/2019. Data yang diperoleh alam penelitian ini dikelompokkan menjadi dua yaitu data kompetensi pengetahuan matematika kelas $V$ kelompok eksperimen di SD Negeri 12 Peguyangan dan data kompetensi pengetahuan matematika kelas $\mathrm{V}$ kelompok kontrol di SD Negeri 5 Peguyangan. Berdasarkan hasil analisis kompetensi pengetahuan matematika kelas eksperimen memperoleh rata - rata gain skor yaitu $\bar{X}=0,54$, standar deviasi $=0,157$, varians $=0,025$, nilai minimum $=0,28$, dan skor maksimum 0,88 . Sedangkan kelas kontrol memperoleh rata - rata gain skor yaitu $\bar{X}=0,39$, standar deviasi $=0,167$, varians $=0,028$, nilai minium $=0,14$, dan nilai minimum $=0,78$.

Dari hasil data perhitungan yang diperoleh, menunjukkan bahwa gain skor kompetensi pengetahuan Matematika siswa kelompok eksperimen yang mengikuti pembelajaran menggunakan model kooperatif tipe Somatic, Auditory, Visual, Intelectual Berbasis TIK memiliki nilai rata-rata lebih tinggi daripada kelompok kontrol. Pengujian asumsi dalam penelitian ini menggunakan statistik inferensial yang meliputi uji normalitas sebaran data dan uji homogenitas varians. Sebelum dilakukan uji hipotesis terlebih dahulu dilakukan uji prasyarat analisis. Uji prasyarat tersebut terdiri dari uji normalitas sebaran data dengan teknik Kolmogorov-Smirnov dan uji homogenitas varians dengan uji fisher.

Uji normalitas sebaran data dilakukan dengan kedua kelompok data yang meliputi data kelompok siswa yang dibelajarkan melalui model pembelajaran Somatic, Auditory, Visual, Intelectual Berbasis TIK dan data kelompok yang dibelajarkan melalui pembelajaran konvensional. Uji ini dilkukan untuk mengetahui sebaran data gain skor kompetensi pengetahuan matematika yang akan digunakan dalam pengujian hipotesis.

Berdasarkan hasil tabel kerja uji normalitas kelompok eksperimen, diperoleh nilai kuartil penguji Kolmogorov-Smirnov yaitu 0,164 pada taraf signifikansi 5\% kemudian dibandingkan dengan tabel Kolmogorov-Smirnov dengan $\mathrm{N}=43$ yaitu 0,207 . Hal ini menunjukkan bahwa $\mid \mathrm{F}_{\mathrm{t}}$ - $\mathrm{F}_{\mathrm{s}} \mid$ terbesar < nilai tabel Kolmogorov-Smirnov yaitu 0,164<0,207 berarti data sebaran kelompok eksperimen berdistribusi normal. Sedangkan hasil tabel kerja uji normalitas kelompok kontrol, diperoleh nilai kuartil penguji Kolmogorov-Smirnov yaitu 0,159 pada taraf signifikansi $5 \%$ kemudian dibandingkan dengan tabel Kolmogorov-Smirnov dengan $\mathrm{N}=35$ yaitu 0,224 . Hal ini menunjukkan bahwa $\left|F_{t}-F_{s}\right|$ terbesar < nilai tabel Kolmogorov-Smirnov yaitu $0,159<0,224$ berarti data sebaran kelompok kontrol berdistribusi normal.

Uji homogenitas varians dilakukan terhadap data kompetensi pengetahuan matematika antara kelompok eksperimen dan kelompok kontrol. Jumlah masing - masing kelas analisis adalah 43 siswa untuk kelas eksperimen dan 35 siswa untuk kelas kontrol.

Berdasarkan tabel tersebut diperoleh $\mathrm{F}_{\text {hit }}=1,12$ sedangkan untuk taraf signifikansi $5 \%$ $\mathrm{F}$ tabel dengan $\mathrm{db}(42,34)$ adalah 1,73. Ini berarti $\mathrm{F}_{\text {hit }}<\mathrm{F}_{\text {tabel }}, 1,12<1,73$ maka data memiliki varians yang homogen. Hipotesis yang diuji dalam penelitian ini adalah tidak Tidak terdapat pengaruh model pembelajaran Somatic, Auditory, Visual, Intelectual berbasis TIK terhadap kompetensi pengetahuan Matematika siswa kelas V SD Gugus Letkol Wisnu tahun ajaran 2018/2019.

Berdasarkan hasil uji normalitas dan homogenitas dapat diketahui bahwa data yang diperoleh dari kelompok eksperimen dan kelompok kontrol berdistribusi normal dan memiliki varians yang homogen.

Karena data yang diperoleh telah memenuhi semua prasyarat, uji hipotesis dilakukan dengan menggunakan analisis uji-t. Berdasarkan hasil analisis uji-t dari kompetensi pengetahuan matematika diperoleh hasil sebagai berikut.

Tabel 01 Rekapitulasi Hasil Uji-t Kelompok Sampel Penelitian

\begin{tabular}{ccccccccc}
\hline No & $\begin{array}{c}\text { Kelompok } \\
\text { Sampel }\end{array}$ & N & Dk & $\begin{array}{c}\text { Rata-rata Gain } \\
\text { Skor }\end{array}$ & $S^{2}$ & $t_{\text {hitung }}$ & $t_{\text {tabel }}$ & Keterangan \\
\hline 1 & Eksperimen & 43 & 76 & $\begin{array}{c}0,54 \\
0,39\end{array}$ & 0,025 & 4,054 & 2,000 & $\mathrm{H}_{0}$ \\
2 & Kontrol & 35 & & 0,028 & & \\
\hline
\end{tabular}


Dari tabel tersebut, hasil analisis uji-t diperoleh $t_{\text {hitung }}=4,054$. Harga tersebut kemudian dibandingkan dengan harga $t_{\text {tabel }}$ dengan $d k=43+35-2=76$ dan taraf signifikansi $5 \%$ sehingga diperoleh harga $t_{\text {tabel }}=2,000$, karena $t_{\text {hitung }}>t_{\text {tabel }}, t_{\text {hitung }}=4,054>t_{\text {tabel }}(\alpha=$ $0,05)=2,000$ maka $\mathrm{H}_{0}$ ditolak. Hal ini berarti terdapat perbedaan yang signifikan model pembelajaran Somatic, Auditory, Visual, Intelectual berbasis TIK terhadap kompetensi pengetahuan Matematika siswa kelas V SD Gugus Letkol Wisnu tahun ajaran 2018/2019.

Rata-rata kompetensi pengetahuan Matematika siswa kelompok eksperimen 0,54 lebih besar dari 0,39 yaitu rata - rata kompetensi pengetahuan Matematika siswa kelompok kontrol. Rata-rata kompetensi pengetahuan Matematika siswa kelompok eksperimen $=0,54>0,39$ rerata kompetensi pengetahuan Matematika siswa kelompok kontrol. Berdasarkan Hasil Analisis Kompetensi Pengetahuan Matematika Kelompok Eksperimen $\bar{X}=0,54$ Standar Deviasi $=0,16$. Sedangkan berdasarkan hasil analisis Kompetensi Pengetahuan Matematika Kelompok Kontrol $\bar{X}=0,39$ Standar Deviasi $=0,17$.

Sehingga dapat disimpulkan bahwa penerapan model pembelajaran Somatic, Auditory, Visual, Intelectual berbasis TIK berpengaruh terhadap kompetensi pengetahuan Matematika siswa kelas V SD Gugus Letkol Wisnu tahun ajaran 2018/2019.

Perbedaan kompetensi pengetahuan pada kelompok eksperimen dan kelompok kontrol disebabkan karena perlakuan berupa model pembelajaran Somatic, Auditory, Visual, Intelectual berbasis TIK pada kelompok ekperimen mampu memberikan siswa pengalaman belajar yang menyenangkan dan tidak membosankan karena dapat melatih alat indera yang di miliki oleh siswa melalui Teknologi Informasi dan Komunikasi. Model pembelajaran Somatic, Auditory, Visual, Intelectual merupakan suatu model pembelajaran yang menekankan bahwa belajar harus melibatkan semua panca indra yang dimiliki oleh siswa. Panca indra siswa harus dapat dimanfaatkan seoptimal mungkin agar dapat memahami tentang konsep maupun permasalahan. Model pembelajaran Somatic, Auditory, Visual, Intelectual diterapkan untuk melatih siswa lebih aktif dalam kegiatan belajar mengajar sehingga kegiatan pembelajaran yang dihasilkan lebih interaktif. Pembelajaran berbasis Teknologi Informasi dan Komunikasi merupakan media penghubung untuk menyampaikan transfer ilmu pengetahuan dari pendidik kepada peserta didik.

Dua unsur penting dalam proses transfer ilmu pengetahuan yaitu unsur media dan pesan yang disampaikan melalui media tersebut. Unsur media menggambarkan Teknologi Informasi dan Komunikasi sebagai jaringan infrastruktur yang menghubungkan pendidik dengan peserta didik, sedangkan unsur pesan menggambarkan konten pembelajaran digital. Selain itu pembelajaran akan menjadi lebih menarik karena guru boleh memodifikasi lagi penggunaan model pembelajaran ini sesuai dengan keinginan dan kebutuhan sesuai situasi pembelajaran, dan model pembelajaran Somatic, Auditory, Visual, Intelectual sehingga proses pembelajaran dapat lebih optimal,menarik, dan mendorong siswa terampil dalam berkomunikasi, terampil mengorganisasikan informasi, dan terbiasa bekerja sama dengan teman dalam proses pembelajaran di dalam kelas. Dibandingkan dengan kelompok kontrol yang menggunakan pembelajaran konvensional, siswa cenderung pasif karena kurang adanya media pembelajaran yang menunjang dan model pembelajaran yang kurang bervariasi dalam proses pembelajaran di kelas. Sehingga siswa kurang memahami materi yang diberikan oleh guru

Penelitian ini diperkuat oleh beberapa penelitian yang relevan, diantaranya yakni penelitian yang dilakukan oleh peneliti: Utama (2014) yang berjudul "Hasil Belajar Matematika siswa yang dibelajarkan dengan model pembelaaran Somatic, Auditory, Visual, Intelectual Berbasis Open ended dengan siswa yang dibelajarkan melalui pembelajaran konvensional pada siswa kelas V SD Gugus III Sukawati." menyimpulkan terdapat perbedaan yang signifikan hasil belajar Matematika siswa yang dibelajarkan menggunakan model pembelajaran Somatic, Auditory, Visual, Intelectual Berbasis Open ended dengan kelompok siswa yang dibelajarkan melalui pembelajaran konvensional.

Berdasarkan paparan hasil penelitian dan pembahasan tersebut, dapat dikatakan bahwa model pembelajaran Somatic, Auditory, Visual, Intelectual berbasis TIK berpengaruh terhadap kompetensi pengetahuan Matematika siswa kelas V SD Gugus Letkol Wisnu tahun ajaran $2018 / 2019$. 


\section{Simpulan dan Saran}

Dari hasil analisis diketahui bahwa sebaran data kompetensi pengetahuan Matematika siswa berdistribusi normal dan memiliki varians yang homogen. Dari hasil analisis diperoleh $t_{\text {hitung }}=4,054$ dan $t_{\text {tabel }}=2,000$ pada taraf signifikansi $5 \%$ dengan $d k=n 1+n 2-2=(43+35-2)$ $=76$. Oleh karena $t_{\text {hitung }} 4,054>t_{\text {tabel }} 2,000$ maka $H_{0}$ yang menyatakan tidak terdapat perbedaan yang signifikan kompetensi pengetahuan matematika kelompok siswa yang dibelajarkan melalui model pembelajaran Somatic, Auditory, Visual, Intelectual Berbasis TIK dengan kelompok siswa yang dibelajarkan melalui pembelajaran konvesional pada kelas V SD Gugus Letkol Wisnu Tahun Ajaran 2018/2019 di tolak dan $\mathrm{H}_{\mathrm{a}}$ yang menyatakan bahwa terdapat perbedaan yang signifikan kompetensi pengetahuan matematika kelompok siswa yang dibelajarkan melalui model pembelajaran Somatic, Auditory, Visual, Intelectual Berbasis TIK dengan kelompok siswa yang dibelajarkan melalui pembelajaran konvesional pada kelas V SD Gugus Letkol Wisnu Tahun Ajaran 2018/2019 diterima. Dilihat dari rata-rata kelompok siswa yang dibelajarkan melalui model pembelajaran Somatic, Auditory, Visual, Intelectual Berbasis TIK X $X_{1}=0,542>X_{2}=0,392$ kelompok siswa yang dibelajarkan secara konvensional. Jadi dapat disimpulkan bahwa model pembelajaran Somatic, Auditory, Visual, Intelectual Berbasis TIK berpengaruh terhadap Kompetensi Pengetahuan Matematika Siswa Kelas V SD Letkol Wisnu Tahun Ajaran 2018/2019.

Adapun saran yang bisa diberikan melalui peneltian ini adalah sebagai berikan: 1) kepada guru disarankan agar lebih kreatif untuk memberikan fasilitas berupa sumber belajar dan kesempatan yang lebih besar bagi siswa pada pembelajaran dengan menggunakan model pembelajaran Somatic, Auditory, Visual, Intelectual Berbasis TIK dan dapat dijadikan alternatif dalam proses pembelajaran untuk membantu peserta didik meningkatkan kompetensi pengetahuan matematika dengan maksimal. 2) kepada Kepala Sekolah, disarankan agar dapat menggunakan hasil penelitian ini sebagai sebagai alternatif dalam mengelola pembelajaran agar sesuai dengan karakteristik pembelejaran Matematika, sehingga mampu meningkatkan pengetahuan dan pemahaman peserta didik tentang Matematika. 3) kepada peneliti lain, disarankan agar hasil penelitian ini digunakan sebagai suatu acuan bagi peneliti lain untuk mengembangkan kemampuan diri dalam mempersiapkan diri sebagai calon pendidik dan meningkatkan pemahaman mengenai kurikulum 2013 dengan penerapan model Somatic, Auditory, Visual, Intelectual Berbasis TIK.

\section{Daftar Pustaka}

Adiana Utara, Wyn. (2014). "Pengaruh Model Pembelajaran SAVI Berbasis Open Ended Terhadap Hasil Belajar Matematika Pada Siswa Kelas V SD Gugus III Sukawati". E-Journal Mimbar PGSD Unversitas Pendidikan Ganeha,(online), Volume 2,Nomor $1 . \quad$ Tersedia pada http://ejournal.undiksha.ac.id/index.php/JJPGSD/article/viewFile/37-3190-1-SM-1 (diakses pada tanggal 27 Januari 2019).

Agung, A. A. G. 2014. Metodologi Penelitian Pendidikan. Yogyakarta: Aditya Media Publishing.

Arikunto, S. 2015. Dasar-Dasar Evaluasi Pendidikan. Jakarta: Bumi Aksara.

Atun, I., \& Rosmala, A. (2018). Model-Model Pembelajaran Matematika. Jakarta: Bumi Aksara

Cahyono, Tri. 2015. Statistik Uji Normalitas. Purwokerto: Yayasan Santarian Banyumas (Yasamas).

Dantes. 2017. Desain Eksperimen dan Analisis Data. Depok: Rajawali Pers.

Nova Kusmayuda, I Gd. (2013). "Pengaruh Model Pembelajaran SAVI Berorientasi Keterampilan Proses Sains Terhadap Hasil Belajar IPA Siswa Kelas V SD Gugus $\checkmark$ Kecamatan Tejakula". Singaraja : FIP Undiksha. Tersedia pada: http://ejournal.undiksha.ac.id/index.php/JJPGSD/article/viewFile/838-1559-1-SM (diakses pada tanggal 28 Januari 2019).

Ramadhani, Aqmaria (2017). "Pengaruh Model Pembelajaran SAVI dan Media Benda Konkret Terhadap Hasil Belajar Materi Sifat - Sifat Cahaya Pada Siswa Kelas V SDN 
Ngadirejo Kota Kediri Tahun Pelajaran 2016/2017”. Kediri : FKIP-Universitas Nusantara PGRI. Tersedia pada http://ejournal.universitasnusantara.ac.id/index.php/JJPGSD/article/viewFile/98a2b 8ad591656ae7a6a7481d7c41ced (diakses pada tanggal 5 Februari 2019).

Rusman. 2015. Pembelajaran Tematik Terpadu. Bandung: PT RajaGrafindo.

Setyosari, Punaji H. 2015. Metode Penelitian Pendidikan dan Pengembangan. Jakarta: Prenada Media Group.

Shoimin, A. (2014). 68 Model Pembelajaran Inovatif dalam Kurikulum 2013. Yogyakarta: Ar-Rzz Media.

Sugiyono. 2017. Metode Penelitian. Bandung: Alfabeta.

Susanto, Ahmad. 2014. Pengembangan Pembelajaran IPS di Sekolah Dasar. Jakarta: Prenadamedia Group.

Undang- Undang No 20 Tahun 2003 Bab 1 Pasal 3 tentang Sistem Pendidikan Nasional. 2003. Jakarta: Presiden Republik Indonesia

Yusuf, Muri. 2015. Asesment Dan Evaluasi Pendidikan. Jakarta : Prenada Media Group 